\title{
Hz. Muhammed (sav) Döneminde Çok Kültürlü Toplumsal Yapısıyla Medine'de “Birlikte Yaşama Modeli"nin Temelleri
}

\author{
Süleyman DİNÇER ${ }^{1}$
}

Öz

Bir kul peygamber olarak Hz. Muhammed (sav), düşmanlığın yerine karşılıklı saygıya dayanan bir "birlikte yaşama modeli’ ideali ile insanlara İslâm’ı tebliğ etmiştir. Ne var ki Mekke müşrikleri, Hz. Muhammed'in (sav) ilahî mesajına karşı çıkmış hem kendisine hem de az sayıdaki Müslümanlara kötü muamelelerde bulunmuştur. Mekke müşrikleri, daha sonra sayıları artmaya başlayan Müslümanlara üç yll boyunca (miladî 616-619) sosyo-ekonomik boykot uyguladıkları için, Müslümanlar için Mekke'de özgürce yaşamak gittikçe zorlaştı. Hz. Muhammed (sav), Medineli Müslümanlarla yapmış olduğu “Akabe Biatleri” ile Medine’ye hicret için gerekli zemini hazırlamıştı. Hicretten sonra Medine'de "Ensar" ile Muhacir arasında sağlanan ilk "Birlikte Yaşama Modeli”nin kapsamı genişletilerek, buna gayriMüslim kavimler de dâhil edilebilmiştir. İşte bu çalışmamızda, değişik inanç gruplarını da içine alan "Birlikte Yaşama Modeli”"nin ilkeleri irdelenecektir. Çalışmamızın gayesi, küresel ırkçılığın ve toplumsal şiddet olaylarının arttığı bir dünyada Hz. Muhammed'in (sav) "Birlikte Yaşam Modeli”nin günümüz toplumsal sorunların çözümüne yönelik katk1 sağlayabileceğini göstermektir.

Anabtar Kelimeler: Hicret, Birlikte Yaşama Modeli, Medine Vesikası, Ensar, Muhacirler

The Basics of "Living Together Model" in Medina with His Multi-Cultural Social Structure during the Epoch of Muhammed (p.b.u.)

\section{Abstract}

As a human being prophet Muhammed (p.b.u.), notified the Islam to people with the ideal of "living together model" which contains mutual respect instead of hostility. Unfortunately the polytheists of Mecca, were against the divine message of Muhammed (p.b.u.), they both behaved badly Muhammed (p.b.u.) and few Muslims. The polytheists of Mecca had implemented socio-economic boycott for three years to all Muslims whose number started to increase day by day (A.D 616-619), for this reason living freely in Mecca became more difficult for Muslims. Receiving the loyalty statement from the Muslims of Medina so-called "Akabe Biatı", Muhammed (p.b.u.) prepared the foundaition for migraion to Medina. After the migration to Medina the scope of "living together model" which was carried out between "Ensar" and immigrants was developed and it included non-muslims. So in this study, the principles of the "living together model", which includes different religion communities, will be researched. The aim of our study is to show that the "living model" of Muhammed (p.b.u.) will be able to contribute to solve the social problems of a world where global racism and violence are increasing.

Key Words: Migration, Living together model, Medina documents, Ensar (Moslems of Medina who helped the immigrants), Immigrants (Muslims who leaved Mecca in order to immigrate to Medina)

\section{Atıf İçin / Please Cite As:}

Dinçer, S. (2020). Hz. Muhammed (sav) döneminde çok kültürlü toplumsal yapısıyla Medine'de "birlikte yaşama modeli"nin temelleri. Manas Sosyal Araștirmalar Dergisi, 9(2), 1248-1259.

Geliş Tarihi / Received Date: 10.04.2019

Kabul Tarihi / Accepted Date: 03.06.2019

\footnotetext{
${ }^{1}$ Kocaeli Üniversitesi, Sosyal Bilimler Enstitüsü, Sosyoloji Ana Bilim Dalı Öğrencisi, slmyndncr@hotmail.com ORCID: 0000-0003-2561-4925
} 


\section{Giriş}

Miladî 569 yllında Mekke'de doğan Hz. Muhammed, vahiy alan bir peygamber olarak İslâm's tebliğ ederken, dünya hayatına yönelik olarak genel anlamda insanlar, özelinde ise Müslümanlar arası sosyal dayanışmanın önemine hep vurgu yapmıştır. Hayati boyunca sosyal barıştan yana olan Hz. Muhammed, doğduğu ve büyüdüğü Mekke’de İslâm'a gönül veren ve birbirleriyle dayanışma içinde olan bir inanç topluluğu oluşturmaya muvaffak olabilmişti ancak Mekke'nin ileri gelen müşrikleri, değil birlikte barış içinde yaşamak, Müslümanlara yaşama hakkını bile fazla görmekteydi.

Kureyş idaresi, genellikle kendi kavminden olduğu halde yeni Müslüman olmuş olan Mekkelilere eza ve cefa çektirmekle yetinmediler aynı zamanda onları Şib’i Ebi Talip denilen bir mahallede abluka alına alıp aç ve susuz bıraktı. Zulümler dayanılmaz hale gelip yaşama hakkı gittikçe zorlaşmaya başlayınca Medineli Müslümanlarla yapılan gizli biatlerin teminatı altında sahabiler, tedricî olarak Mekke'den 473 kilometre uzaklikta olan Medine'ye hicret etmeye başladı. Yesrip olarak bilinen Medine'ye ulaşan sahabiler, aileleriyle birlikte Medineli Müslümanların himayesine alınmaktaydı. Peygamberliğin 13. yllında 53 yaşlarına girmiş olan Hz. Muhammed, Ebu Bekir ile birlikte miladî 622 yllında Mekke'yi terk edenlerin en sonuncularından oldu.

Hicret döneminde Medine, multi-kültürel bir yapıya sahipti. Şam ile Mekke arasında olan ve üç tarafi dağlarla çevrilmiş olan Medine'nin kuruluşu, Amelika'lılara dayanmaktadır. Tevrat'a göre Amelika'lılar, gelmiş geçmiş en eski Arap kabilesi olarak bir göçebe Sâmî topluluğudur (1989, s. 556-558). Amelikalıların reisi Yesrip bin Ubeyl, zamanında kavmiyle birlikte Güney tarafı ova olan bu beldeye yerleşmiş ve burada oluşan yerleşim bölgesine onun adına izafeten Yesrip denilmiştir.

Kudüs şehrinin Romalılar tarafindan işgal edilmesinden dolayı birçok Yahudi Kabilesi, Hayber ve Medine bölgesine kaçmıştı. Medine’ye yerleşen Yahudi kabilelerin başında Beni Kureyza, Beni Kaynuka ve Beni Nadir bulunmaktaydı. Medine'de sadece Yahudiler yaşamamaktaydı. Yemen'de yaşanan bir sel felaketinden dolayı yurtlarını terk etmek mecburiyetinde kalan Evs ve Hazrec kabilelerinin atalarından bir grup da Medine'ye yerlești. Medineli Arapların ekseriyeti (Evz ve Hazrec kabileleri), hurma bahçelerinde çalışır ve çiftçilik ile geçimini temin ederdi. Yahudiler ise daha çok ticaret ve kuyumculuk ile meşgul olurdu.

Servet, sanat ve kültür bakımından Medineli müşrik Araplara göre daha üstün olan Yahudiler, Evz ve Hazrec kabilelerini zamanla ekonomik yönden sömürmeye başladı. Buna bağlı olarak Medineli müşrik Araplarla Yahudiler arasında zaman zaman savaşlar da meydana gelmekteydi. Bununla birlikte Yahudilerin kışkırtmalarıyla iki Arap kavmi olan Evs ve Hazrec kabileleri de kendi aralarında kavgalı hale getirildi. Bu gergin durum, hicretin gerçekleştiği dönemde de Medine'de hâkimdi. İște böyle kaotik bir toplumsal yapıya sahip olan Medine'ye bir de muhacirlerin yerleşmesi ile beraber "birlikte yaşama" daha da riske girmiş oldu.

Ne var ki Hz. Muhammed, bir peygamber olmanın ötesinde kul peygamber olma özelliğini ön planda tutarak, sosyal liderlik marifetiyle değişik inanç ve etnik kökenli grupların bir beldede nasıl birlikte barış içinde yaşayabileceklerinin projesini de ortaya koyabilmişti. Isşte bu makale, Hz. Muhammed'in gerek Müslümanlar arası gerekse Müslümanlarla Müslüman olmayanlar arasında sağladığı "birlikte yaşama modeli"nin oluşum ve gerçekleşme sürecini sosyolojik tahlillerle ele alacaktır.

\section{Medine'de Müslümanlar Arası Dayanışma Toplumun Temelinin Mekke'de Atılması}

Hz. Muhammed, Mekke'de sahabelerin hayatını tehlikede görmekteydi ve Müslümanların Medine'ye hicret etmelerine Medineli Müslümanların kendisine biat etmelerinden yani bağlılık yemininde bulunmalarından sonra müsaade etmiştir. Mekkeli Müslümanların hicretten sonra Medine'de huzur içinde yaşayabilmelerinin temini için, birkaç yıl öncesinden Medineli insanlarla temasa geçmiş ve İslâm'ı kabul edenlerden (Ensar'dan) Mekke'nin iki kilometre dişında Akabe isminde dar bir vadide gizlice buluşmuş ve onlardan her defasında sadakat üzere söz almıştı.

\section{Birinci Akabe Biatı}

Medineli Yahudiler, Medine'de mukim iki Arap kavmi arasındaki ihtilafin devam etmesi için, Hazreclilere karşı Evs kabilesi ile anlaşınca, Hazrecliler, miladî 620 yllında bir müttefik bulmak ümidiyle hac mevsiminde Mekke'ye altı kişilik bir heyet gönderdi (Ülkü, t.y.: 155). Medine'den Mekke'ye hac için gelen Hazrec kabilesinden bu altı kişi, kendilerine destek vere Hz. Muhammed'in sayesinde Müslüman 
oldu. Evs'li Müslümanlar, gelecek yıl yine aynı yerde buluşacaklarına söz verdi. Birinci Akabe Biatinde Müslüman olan bu Medineli Araplar, şirk koşmayacaklarına, hayırlı hiçbir işte Hz. Muhammed'e muhalefet etmeyeceklerine dair yemin ettiler.

\section{İkinci Akabe Biatı}

621 yllında içlerinde bir sene önce Müslüman olmuş altı Hazreclinin de bulunduğu on iki kişiden oluşan bir Medineli grup, yine Mekke'ye geldi. Ancak bu sefer içlerinde Müslüman olmaya karar veren Evs kabilesinden Araplar da vardı. Her iki kabilenin üyeleri, Hz. Muhammed'in huzurunda yine aynı yerde Allah'a hiçbir şeyi ortak koşamayacaklarına, hırsızlık yapmayacaklarına, zina etmeyeceklerine, çocuklarını öldürmeyeceklerine, iftira atmayacaklarına ve hayırlı hiçbir işe karşı çıkmayacaklarına dair söz verdi. Bunun yanında Hz. Muhammed'e, refahta olduğu kadar sıkıntı da sevinçte olduğu kadar üzüntüde de dinlemek ve itaat etmek üzere yemin ettiler (Gadban, 1990, s. 61-63).

Hz. Muhammed'i, kendi nefislerinden daha üstün tutacaklarını yemin eden Medineli Müslümanlar, böylece Hz. Muhammed'i manevî ve siyasî lider olarak kabul etti. Bu söz verme, vahye dayanan bir sosyal nizamın oluşturulmasına yönelik bir nevi sosyal ve siyasî bir mukavele olması hasebiyle ileride Medine'de kurulması düşünülen İslâm toplumunun meşru dayanağını teşkil etmekteydi. Bu ikinci biatten sonra sahabilerin bir kısmının gizlice Medine'ye hicret etmelerine izin verildi (Ülkü, t.y.:139)

İslâm’1 daha iyi öğrenebilmeleri için, Hz. Muhammed, genç sahabilerden olan Musab bin Umeyr’i muallim olarak vazifelendirdi ve ona Medine'ye gitmesini emretti (Yeniçeri, 1994, s. 246; İbni Hişâm, C. 2, s. 75-76). Bir Kur'an hocası olan Musab bin Umeyr, Medine'ye ulaştığında Medineli Müslümanların bir nevi önderliğini yapan Esad bin Zürâre'nin evinde kaldı. Bu ev, Medineli Müslümanların eğitim ve tebliğ merkezi fonksiyonu görmeye başladı.

\section{Üçüncü Akabe Biatı}

İleride örgütlü bir İslâm toplumu oluşturma niyeti, 622 y1lında Evs ve Hazreç kabilelerine mensup ikisi kadın 75 Medineli Müslümanın katıldığı 3. Akabe Biatinde daha da belirginleșmiş oldu. O senenin hac mevsiminde, İslâm'ı tebliğ etmekle görevli Musab bin Umeyr de Medineli Müslümanların arasında bulunmaktaydı. Hz. Peygamber (sav) gece yarısı gizlice buluştuğu Medineli Müslümanlardan şu konularda biat istedi: “Allah'tan başka ilah bulunmadığına ve benim de Allah'ın Resulü olduğuma şehadet getirerek, namazı kılacağınıza, zekâtı vereceğinize, neşeli ve neşesiz zamanlarınızda sözlerime itaat edeceğinize, emirlerime bütünüyle boyun eğeceğinize, darlıkta da varlıkta da muhtaçlara yardımda bulunacağınıza, hiçbir kınayıcının kınamasından korkmaksızın Allah yolunda, Allah için hakkı söyleyeceğinize, iyiliği emredip kötülükten alıkoyacağınıza biat etmeli, bana kesin söz vermelisiniz. Şahsıma gelince, bana her yönden yardım edeceğinize, yanınıza vardığımda, kendisiniz, kadınlarınızı ve çocuklarınızı esirgeyip koruduğunuz şeylerden beni de esirgeyip koruyacağınıza söz vermelisiniz.” (İbni Hişâm, C. 2, s. 97).

Gönülden biat aldıktan sonra Hz. Muhammed, Evs ve Hazreç kabilelerinden olmak üzere her bir Medineli ailenin başına bir temsilci/yönetici (nakib) olmak üzere 12 nakib tayin etti ve bunların başına da Hazreçli ileri gelenlerinden olması dolayısıyla temsilci olarak seçilen Esad bin Zürare'yi de baş idareci (nakibu'n-nukaba) olarak tespit etti. Ancak bu (baş) yöneticiler, cahiliye döneminden kalma 1rk ve kabile taassubundan uzak ümmet bilinci ile herkese âdil davranmakla yükümlüydüler. İkinci biatte temeli atılmış olan İslâm toplumunun ilk idarî yapısı ve örgütlenmesi böylece 3. biatle şekillenmiş oldu (Ağırakça, 2016, s. 14; Yeniçeri, 1994, s. 247).

Zulüm altında olan Mekkeli Müslümanların yakın zamanda Mekke'den Medine'ye hicret edeceklerini anlayan Medineli Müslümanlar, İslâm toplumu için her türlü fedakârllğa hazır olarak Mekke'den ayrıldılar. Henüz resmî olarak bir Müslüman toplumu kurulmamıştı ama ileride oluşturulacak birlikte yaşama modelinin örgütsel yapısını oluşturacak olan üyeleri arasında gönüllülük esasına dayanan bir sosyal sözleşme (biat) Hz. Muhammed’in (sav) inisiyatifi ile yapılabilmişti (Aydın, 1991, s. 213).

Böylece Akabe Biatleri, aristokratik (pederşahi) ve despotik bir yönü olan Mekke devletinin haberi olmaksızın tam gizlilik esasları doğrultusunda gerçekleșmiştir. Müslümanların güvenliği için, İslâmî diplomasinin yanında istihbarat sistemi de bu vesile ile geliştirilmiş oldu. Bir taraftan zor durumda olan Müslümanlara yardımcı olmak isteyen güvenilir Gayri-Müslimlerden istifa edilmiş, diğer taraftan da bu kişiler aracillğıyla düşman kamplarından bilgi edinilmiştir. Özellikle bir siyasî ve idarî zaruret olarak $\mathrm{Hz}$. Muhammed'in amcası ve onun hamisi Abbas, henüz Müslüman olmadığ1 halde, bu gizli toplantıların organizasyonunda önemli bir rol üstlenmiş ve bizzat bu görüşmelerde hazır bulunmuştur (Gadban, 1990, s. 70-82). 


\section{Ensar ile Muhacirler Arasında Birlikte Yaşama Modelinin Temelinin Medine'de Atılması}

Hz. Muhammed, çok kültürlü bir sosyal yapıya sahip olan Medine'ye hicret ettikten sonra (miladî 622) ilk önce Medineli yerli Müslümanlar (Ensar) ile Muhacir Müslümanlar arasında yakınlaşmayı sağlayan adımları attı. Muhacir Müslümanlar, sadece Araplardan değil Bilal-i Habeşî gibi Afrikalılardan ve Selman bin Farisi gibi İranlılardan oluşmaktaydı. Hz. Muhammed, değişik bölge, soy ve 1rklardan gelen ve değişik diller konuşan Müslümanları Mekke'de nasıl bir araya getirebildi ise bu birlikteliği daha geniş kapsamda devam ettirmek istiyordu. Bu doğrultuda Hz. Muhammed, Müslümanlar arası kardeşlik duygularına bağlı sosyal yardımlaşmayı teşvik etmiş, kan, dil ve ırk gibi etnik ve kültürel unsurların üzerinde bir ümmet bilinci oluşturmuş ve Müslümanların mekân ve zamandan bağımsız olarak birlikte yaşama modelinin temelini oluşturmuştur.

\section{Ensar ve Muhacirler Arasında Manevî ve Sosyal Kardeşliğin Tesisi}

Müslümanlar arası birlikte yaşama kültürünün oluşturulabilmesi ve sürdürülebilmesi, manevî kardeşlik duygusunun pekiştirilmesi ile mümkündür. Nitekim Allah, Kur'an'da "Müminler, yalnızca kardeştir." (Hucurat: 49/10) demek suretiyle Müslümanlar arasındaki manevî kardeşlik bağını âdeta kan bağı bulunan kardeşler seviyesine çıkartmıştır. Böylece kan kardeşliğinde olduğu gibi, Müslümanlar da aynı inancı paylaşan manevî kardeşlerine sosyal dayanışma noktasında kendilerini vicdanen sorumlu hissetmiştir/hissetmektedir.

İlk inen ayetler de bu doğrultuda, Müslümanların sosyal dayanışma içinde bulunmalarını emretmekteydi. İslâm'a giren ilk dönemin Müslümanları, kendi aralarında sosyal dayanışmada bulunarak, Mekke'de yaşadıkları baskı ve zorluklara karşı direnebilmiştir. Çünkü ilk Müslümanlar, Mekke döneminde 13 yıl boyunca hem sosyo-ekonomik, hem de dinî özgürlükler açısından çok sıkıntılı bir dönem geçirmişti.

Allah, o dönemin şartlarına uygun olarak "Namazı dosdoğru kılın, zekâtı verin, Allah'a (O'nun rızası uygun olarak muhtaçlara faizsiz) güzel borç verin.” (Müzemmil: 73/20) diyerek hem ferdî hem de sosyal ibadetleri bir bütünlük içinde aynı kategoride değerlendirmiştir. Buna göre Müslümanlar, namazlarını ihlâsla kılmaları gerektiği gibi, aynı hassasiyetle miktarı, zamanı ve türü somut olarak henüz belirtilmemiş olsa da Allah rızasını kazanmak adına yardıma muhtaçlara karşılıksız olarak zekât ve(ya) geri ödemeli faizsiz borç vermekle yükümlüdür. Bu bağlamda duyarlı Müslümanlar, fedakârlık gösterip desteğe muhtaç Müslümanları sosyal koruma kapsamına alır (İnsan: 76/8).

Bu sosyal mesajların muhatapları olan zengin ve güçlü Müslümanlar, Hz. Muhammed'in direktifleri doğrultusunda Mekke müssrikleri tarafından zulme uğrayan köleleri satın almış ve onların özgürlüklerine vesile olmuştur. Örneğin ticaretle uğraşan ve dolayısıyla maddî durumu gayet iyi olan Ebu Bekir, köle statüsünde olan fakat Müslüman oldukları için fazlasıly eziyet gören Habbab bin Eret ve Bilal bin Rebah'ı satın almış ve onların hür olmalarını sağlamıştır.

Hicretten sonra başlayan Medine hayatı ise Müslümanlara her ne kadar yaşama ve inanç özgürlüğü getirdi ise de ilk dönemlerde ekonomik refah sağlayamamıştı. Medine'ye hicretle birlikte muhacirlerin hemen hepsi, bütün varlıklarını Mekke'de bıraktıkları için, maddî sıkıntılar için düşmüştü (Aşur, 2000, s. 180). Hicret edenler; Mekke'de evini, bağını, bahçesini, iş yerini topyekûn her şeyini bırakarak yeni bir hayata başlamışı. Hicretle birlikte Medine'de âdeta nüfus patlaması olmuştu. Yerli halkın zor hayat mücadelesine, bir o kadar işsiz güçsüz, evsiz barksız göçmen ilave edilmişti. Üstelik Müslümanlar arasında zengin olanların sayısı da o dönemlerde çok az idi (Yardım, 1998, s. 442).

Dolaysıyla yoksullukla mücadele noktasında toplum nezdinde sosyal dayanışma açlımlarına ihtiyaç vard1. Hz. Muhammed, Medine'ye gelmesinden beş ay sonra, zor durumda kalan muhacirlerin durumlarını iyileştirmeye yönelik olarak Muhacirlerle Ensar arasında bir kardeşlik anlaşmasının yapılmasını önerdi. Bu öneri, Kur'an'ın “Ancak müminler kardeştir” (Hucurat: 49/10) temel ilkesine tamamen uygun olduğu gibi kardeşliğin sosyal ve siyasî birliğe dönüştürülmesinin somut tezahürü idi. Bu bağlamda kardeşlik, İslâm birliğine ve hatta devletine inanmış şuurlu Müslümanların müşterek vasfidır (1991, s. 115).

Ensar, İslâm kardeşliğinin şuuruyla muhacirlere her türlü yardım yapma konusunda âdeta yarış halindeydiler. Hayır yapmakta o kadar ileri bir konumda idiler ki, ev ve bahçeleri dâhil her şeylerini bütünüyle vermeye razı idiler. Hz. Muhammed, bunu fazla buldu ve şöyle bir fikir önerdi: Muhacirler, Ensar'ın evlerinde ikamet edebilmeli, bağ ve bahçe işlerinde onlara yardımcı olmalı ve elde edilen 
gelirlerden yarı yarıya yararlanmalıdır. Bu fikir doğrultusunda her iki Müslüman grup, sosyal kardeşlik şuuruyla birbirleriyle kaynaşmış oldu. Daha somut bir ifadeyle 186 muhacir ailesi, aynı sayıdaki Ensar ailesinin yanına yerleştirildi. Muhacirler, manevî kardeşlik sorumluluğun bir gereği olarak Ensar'a değişik işlerde beden gücüyle destek oldu. Bu durum, hicri 7. ylla Hayber'in ele geçirilmesine kadar devam etmiştir (Aydın, 1989, s. 364).

\section{Ashab-1 Suffe: Bekâr ve Kimsesiz Muhacirlerin Özel Olarak Sosyal Koruma Altına Alınması}

Hz. Muhammed'in liderliğinde Medine'nin yerleşik Müslümanları olan Ensar ile Mekke'den Medine'ye hicret eden Müslümanlar arasında tesis edilen kardeşlik paktı sayesinde Müslümanlar arası sosyal yardımlaşmanın ilk hamleleri atılmış oldu. Böylece Medineli Müslüman ailelerden her biri, bir Mekkeli aileyi evinde misafir olarak kabul etmek suretiyle iskân sorunu çözülmüş oldu. Her iki ailenin fertleri, manevî kardeşlik şuuruyla hemen her hususta birlikte hareket etti. Servetlerini paylaştılar, bağ ve bahçelerde birlikte çalş̧tlar ve(ya) pazarda ortaklaşa ticaret yaptılar.

Ensar ile kaynaştırlamayan özellikle bekâr ve kimsesiz muhacirler ise inşa edilen Mescid-i Nebevi'nin "Suffe" ismi verilen bir bölümüne yerleştirildi. Ashab-1 Suffe olarak tarihe geçecek bu Müslümanlar, muhacirlerin en fakirleriydi. Kendisi de Ashab-' ${ }^{\prime}$ Suffe'den olan Hz. Ebu Hureyre der ki:

"Suffe ashabından yetmiş kişiyi gördüm de hiçbirinin bir cübbesi dahî yoktu. Üzerlerinde ya peştamal ya da boyunlarına bağladıkları, bazısı dizlere, bazısı da topuklara kadar ulaşan bir hırka vardı. Avret yeri görülmesin diye de bu hırka önden elle toplanırdı.” (Rûdanî, s, 364)

Ashab-1 Suffe'nin üyeleri, beş vakit namazlarını sürekli olarak Hz. Muhammed ile birlikte kılarlardı. Hz. Muhammed, açlıklarını giderebilsinler diye o dönemin sıkıntılı şartlarına göre onlara hurma temin ederdi. O dönemde yoksul Müslümanlara hurma dahî zor bulunmaktaydı. Rivayetlere göre ancak Hayber fethinden sonra Müslümanlar hurmaya doyabilmişti (Rûdanî, s, 360).

Kur'an, yoksulluğun geçici olduğunu, yoksul muhacirlerin ileriki tarihlerde zenginleşeceğini ifade etmektedir. Allah, özellikle Mekke'de zulme maruz kaldıktan sonra, memleketlerinden, güç ve gönül birliği yapmak için Medine'ye hicret edenleri bir taraftan maddî sıkıntılara karşı gösterdikleri sabır ve tevekkül hasletlerinden dolayı övmekte, diğer taraftan da onlara dünyevî ve uhrevî mükâfatlar verileceğini müjdelemektedir.

"Zulme uğradıktan sonra Allah yolunda hicret edenlere gelince, onları dünyada hasenelerle (iyiliklerle, refahla) yerleştireceğiz. Eğer bilirlerse ahiretin mükâfatı elbette daha büyüktür. Onlar (eziyetlere ve s1kintılara) sabredenler ve Rablerine tevekkül edenlerdir." (Nahl: 16/41-42).

Göçün getirdiği sosyo-ekonomik sıkıntılar, bugünün göç politikalarına da yön verecek şekilde Ensar'ın cömertliği ve fedakârllğı ile giderilebilmiştir. Yüce Allah'ın Medine'de vahyolunan aşağıdaki âyette belirttiği gibi, yurtlarından ve mallarından edilmiş olan muhacirlerin ekseriyeti ve özellikle ashab-1 suffe yoksulluğa düşmüştü. Bu sosyal sorununun giderilmesi için elde edilen (kamusal) gelirlerin önemli bir kısmı da öncelikli olarak yoksul göçmen Müslümanlara verilmeli idi. İlgili âyet, bunu açıcça emretmektedir:

“(Ganimet malları), bilhassa Allah'tan bir lütuf ve hoşnutluk ararken ve Allah'ın dinine ve peygamberine yardım ederken, yurtlarından ve mallarından uzaklaştırılan fakir Muhacirlerindir. İşte onlar doğru kimselerin ta kendileridir." (Haşr: 59/8).

Medine'nin ticaret hayatına yavaş yavaş hâkim olmaya başlayan muhacirler, zamanla Medine'nin de en zenginleri oldukları gibi sosyal ve manevî sorumluluklarını unutmayarak, kazançlarını yine İslâm uğruna ve yoksul Müslümanlar için sarf ettiler. Hz. Muhammed, Ensar ve Ashab- Suffe dâhil bütün Muhacirleri birbiriyle kardeş ilan etmek suretiyle, sosyal kaynaşma sürecinde Medineli ve Mekkeli Müslüman topluluğun zayıf ve güçlü yönlerinin buluşmasını ve her iki tarafin zayıf yönlerinin diğer tarafın güçlü yönleriyle ortadan kaldırılmasını sağlamıştır. Böylece karşılıklı sosyal dayanışma içinde olan ideal bir İslâm toplumu meydana getirilmiş ve bundan da özellikle en çok korunmaya muhtaç konumunda olan ashab-1 suffe yararlanmıştır (Kundurac1, 2012, s. 206-207). 


\section{Müslümanlarla Gayri-Müslimler Arasında Birlikte Yaşama Modelinin Temelinin Medine'de Atılması}

Medine, birden fazla inanç topluluğunu içinde barındıran bir kentti. Burada hicretten sonra yerli ve göçmen Müslümanların yanında çok sayıda putperest/müşrik Araplar (Evs ve Hazrec kabileleri), Yahudiler ve az sayıda Hıristiyan da yaşamaktaydi. Hz. Muhammed, Medine'nin gerecek demografik yapısını belirleyebilmek için, hicretten hemen sonra nüfus sayımı yaptırmıștır. $\mathrm{Bu}$ bağlamda $\mathrm{Hz}$. Muhammed, görevlendirdiği sahabilerine, "Müslüman olduğunu sözü ile açıklayanları bana yazınız" buyurmuştur (Buharî, s. 181; Müslim, s. 235).

Araştırmacılara göre hicretin ilk dönemlerinde Medine'de yaklaşık olarak 1.500 Müslüman, 4.000 Arap müşrik ve 4.500 civarında Yahudi yaşamaktaydı. Dolayısıyla Medine'nin toplam nüfusu 10.000 civarındaydı. Medine'de yaşayan Müslüman nüfusun bu dönemde Medine toplam nüfusunun yaklaşık yedide birini oluşturduğu tahmin edilmektedir (Hamidullah, 1993, s. 183).

Ensar ile Muhacirin Medine'de manevî duygularla birlikte kardeşçe yaşama zaruretinin bir sebebi de iç ve dış tehlikelerdi. Çünkü hicretten sonra da Müslümanlar, Mekke müşriklerinin tehdidi altında halen güven ortamından uzaktı. Mekke devletinin askerleri Medine'de yaşayan yerli ve muhacir Müslümanlara her an saldirabilirdi.

Diğer taraftan toplumsal yapının değiştiği Medine'de yaşayan gayri-Müslim toplulukların, bu süreçte İslâm düşmanlığında bulunma ve(ya) veya Müslümanlar üzerinde hâkimiyet kurma riski de vardı. Örneğin Medine'nin yerli bir müşrik Arap kabilesi olan Hazrecîler, liderleri konumunda olan Abdullah bin Übeyy bin Selûl'ü Medine'nin kralı yapma çabasındaydı (Sönmez, 2007, s. 134).

$\mathrm{Bu}$ iki tehlikeyi bertaraf etmek düşüncesiyle $\mathrm{Hz}$. Muhammed, Medine'de bütün gayri-Müslim toplulukların liderleriyle sosyal diyaloga geçerek, hemen herkesin kabul edebileceği cazip bir "birlikte yaşama modeli” teklifinde bulundu (Sırma, 1994, s. 16-17). Teklifin cazipliği, Medine'de değişik topluluklar arasında barışı ve güvenliği tesis edecek bir idarî sistemin oluşturulamamış olduğu ile yakından ilgilidir. Çünkü Medine'de uzun bir dönemden beri bitmek bilmeyen hem aynı inancı paylaşan kabileler arasında kardeş savaşları, hem de değişik dinlere mensup topluluklar arasında kan davaları meydana geliyordu. Hicretten önce Medine, anarşik ve kaotik bir yapıya sahipti, hemen herkes birbiriyle kavgalı veya savaş halinde idi.

Örneğin Evs ve Hazrec isimli iki Arap kabilesi, genelde Yahudilerin kışkırtmalarıyla hicretten 120 yıl öncesine kadar birbirleriyle hep savaş hâlindeydiler. Hicretten beş yll kadar önce bu iki Arap kabilesi arasında Hazreclilerin mağlup olduğu şiddetli bir savaş meydana gelmişti. Bunun için aralarındaki kin ve düşmanlık, had safhadaydı. Evs ve Hazrec kabilelerine mensup bazı Arapların Hz. Muhammed'e Akabe'de biat etmeleriyle birlikte bu iki kabileden Müslüman olanların sayıs1 azımsanmayacak kadar artmaya başlamıştı. Dolayısıyla Hz. Muhammed'in "birlikte yaşama modeli" teklifi, Evs ve Hazrecliler arasında barışın sağlanmasını temin eden büyük bir firsattı (Ağırakça, 2016, s. 212-215).

Hz. Muhammed, Medine'de herkesin güven içinde yaşayabileceği âdil bir idarî model oluşturmak maksadıyla Medine'deki dinî ve etnik grupların reisleriyle bir araya gelerek, onlara ortak bir yaşama modelinin gerekliliğinden ve toplumsal faydalarından bahsetti. Emniyetsizlik içinde huzursuz bir bölgede yaşamanın getirdiği bıkkınlık ve çaresizliğin karşısında Hz. Muhammed'in bu teklifi, önde gelen cemaat ve kanaat liderlerine son derece cazip geldi. Sonuçta Medine'de tarihinde ve belki de dünyada ilk kez Hz. Muhammed'in başkanlığında idarecilerin ve idare edilenlerin hak ve görevlerinin yazılı olarak belirlendiği bir şehir devletinin temeli atıldı.

\section{Birlikte Yaşama Modelinin Anayasası: Medine Vesikası}

Birlikte yaşama modelinin belirleme sürecinde Müslümanların birliğini sağlayan Ensar-Muhacir kardeşlik anlaşmasından sonra dinler üstü bir yapıya sahip Medine'de yaşayan her bir insana eşit vatandaşlık statüsünü kazandıran bir üst antlaşma projeksiyonun somut adımları atılmış oldu. Medine Vesikası (kitap, sahife) olarak tarihe geçen bu üst antlaşma, birlikte yaşama modelinin şeklini ve idarî biçimini belirleyen birçok maddeden oluşan bir yazılı metindir. Bu vesika klâsik eserlerde (İbn Hișam ve Ebu Ubeyd'in eserlerinde) düz bir metin iken, Alman oryantalist Wellhausen (1844-1918), ilgili eserinde (1889) bunu 47 maddede toplamıştır. M. Hamidullah ise kimi maddeleri kendi içinde bölerek, madde sayısını 52'ye çıkarmışır (Ağırakça, 2016, s. 21-29). 
Medine vesikası, hukuk tarihi açısından konfederatif anayasal devletin ilk örneklerinden kabul edilmektedir. İlgili vesikanın varlığı hususunda bir şüphe bulunmamakla birlikte, anayasa kitabının bütünü tek bir oturumda m1 yoksa gelişmelere bağlı olarak bazı ilave maddeler eklenerek mi hazırlandığ noktasında tam bir fikir birliği yoktur. Büyük bir ihtimalle Müslümanlar (Ensar ile Muhacirler) ile ilgili bölüm (1-23. maddeler), hicretten hemen sonra kaleme alınmıs,, Yahudilerle ilgili diğer maddeler ise Bedir Muharebesinden sonra ilave edilmiştir (Ağırakça, 2016, s. 212-215).

Nitekim Medine Vesikasının içeriğine bakıldığında ilk 23 maddenin Müslümanlarla, 24-47 arası maddelerin ise ağırlıklı olarak Medine'de yerleşik olan diğer kabilelerle ilgili olduğu görülecektir (Sönmez, 2007, s. 84-93).

Medine vesikası, bu hâliyle Medine'de yaşayan Müslüman topluluk (İslâm ümmeti) ile gayri-Müslim Arap ve Yahudi kabileleri ile bir konfederasyon çatısı altında uzlaşarak, federatif niteliği olan birlikte yaşama modelinin anayasası olarak değerlendirilebilir. Her bir federasyon (etnik-dinî grup), tasarlanan "Birlikte Yaşama Modeli"nin içinde kendi muhtariyetini (özerkliğini) koruyabilme hakkını elde edebilmişti. Medine halkına birçok sosyal hak tanıyan bu vesikanın "Birlikte Yaşama Modeli"nin unsurlarını oluşturan maddelerin tek tek analizinin yapılmasında fayda vardır (Hamidullah, 1992, s. 39-41; Ağırakça, 2016, s. 212-215).

\section{Müşterek Devletin İlanı ve Başkanı}

Birlikte barış içinde yaşamayı imkân tanıyan Medine devletinin vatandaşları, Müslümanlardan ve diğer Gayri-Müslimlerden oluşmaktadır. Hz. Muhammed, kurulan yeni devletin başkanı olarak belirlenmiştir (m. 1). Hz. Muhammed hem idarî hem de adlî yönden bütün federasyonların (dinî cemaatlerin) başındaki en yetkili isim, en son yargı merci (mm. 23, 42) ve ordu kumandanıdır (m. 36). Hz. Muhammed, bütün federatif üyeler tarafından sadece devletin başı olarak değil aynı zamanda Allah'ın elçisi olarak da kabul edilmiştir (mm. 42, 47). Dolayısıyla tevhit dinine bağlı bir (İslâm) devlet modeli, bütün kurucu üyeler tarafindan kabul görmüştür. Buna göre olası anlaşmazlıklarda Allah'ın kanunları yegâne mercidir.

\section{Vatandaşların Can Güvenliği ve Yurt Savunması}

Medine ve çevresi, haram bölgesi olarak belirlenmiştir. Her bir cemaat, kendi bölgesinden sorumlu olmakla beraber antlaşmaya dâhil olan herkes, Medine ve çevresinde can güvenliğine sahiptir. Medine devletinin dış saldırılara karşı gönüllülerden oluşan müşterek bir savunma sisteminin oluşturulması esastır. Savunma sorumluluğu, Medine'nin yerli ve göçmen Müslümanları ile Medine'de yaşayan diğer grupların üyelerine aittir. Buna göre her grup, kendi savunma masraflarını üstlenir. Ancak herhangi bir savaş olduğunda, kimin savaşa katılacağı ve(ya) devlet başkanına kimin refakat edeceği kararını $\mathrm{Hz}$. Muhammed karar verir (mm. 18, 37, 44, 45). Medine devletinin gayri-Müslim üyeleri, İslâm'a düşmanca bakan Mekkeli Kureyşlilerle anlaşma yapamaz ve onları himaye edemez (mm. 20 b, 43).

\section{Toplulukların Sosyal Sorumlukları}

Her bir federatif unsur, kendi içinde bağımsızdır. Dolayısıyla Gayri-Müslimler, idarî ve adlî yönden özerktir. Diyet, kurtuluş fidyesi, savaş masrafları gibi sosyal, hukukî, malî ve askerî konular, her federatif üye tarafından kendi bünyesinde çözülür (mm. 3-12, 37, 38). Müslümanlar, 12. maddeye göre, birbirleriyle sosyal dayanışma içinde bulunur. Bunun ötesinde kendi aralarında fidye ve diyeti makul ölçülere göre öder. Daha somut bir ifadeyle malî sıkıntı içinde olanlar kurtarılmalı, esirlerin fidyesi (kurtuluş bedeli) ödenmeli ve hataen katil olaylarında diyetler hak sahiplerine verilmelidir (mm. 3-12).

\section{Toplulukların Hukukî Sorumlulukları}

Her toplum, yargı görevini kendi hukuk sistemi içinde bağımsız olarak yürütür. Ancak farklı dinî ve etnik cemaatlere mensup kişiler arasında bir anlaşmazlık gibi hukukî bir sorun yaşandığında son yargı merci federal devletin başkanı Hz. Muhammed olarak belirlenmiştir (mm. 23, 42): Kan diyeti ve kurtuluş fidyesi gibi meselelerde sosyal yardımlaşma esastır ve eşitlik ilkesi geçerlidir. Adalet ilkesi gereği mazluma yardım edilir ve suçlular hiçbir surette korunmaz. Bu vesika hükümleri, suç işleyenleri cezalandırmaya engel olarak yorumlanamaz. Devlet bünyesinde oluşturulan federasyonlar ve bu federasyonlara mensup fertler, haksızlığa karşı gerekli tedbirleri alır ve haksızlıkta bulunanların yanında yer almaz (mm. 13, 21). 


\section{Bir Üst Kimlik Olarak İnsan Topluluğu (Nâs/Ümmet) Hukukunun Tesisi}

Devlet, Müslümanların ve diğer inanç gruplarının dinî hürriyetlerine müdahale etmez. Her bir cemaat, bir ümmettir. Yahudilerin dinleri kendilerine, müminlerin dinleri de kendilerinedir (m. 25). Medine Vesikasının 25. maddesinde yer alan ve birliğe katılan Benü Avf kabilesi, bir Yahudi cemaati idi. $\mathrm{Bu}$ cemaat, Medine topluluğu içinde İslâm ümmetinin dişında bir ümmet olarak kayda geçmiştir. Bu ifadeler, Kur'an'da 64 kez geçen ümmet kavramına verilen anlamlara da uygun düşmektedir. Kur'an, "İnsanlar (önceden) tek bir ümmetten başka bir şey değildi sonra ayrilığa-anlaşmazlığa düştüler." (Yunus: 19/10) demek suretiyle insan topluluklarının zaman içinde değişik ümmetlere bölündüğünü açıklamaktadır. Dolayısıyla Kur'an'ın insan topluluklarının oluşum ve gelişim sürecinin son merhalesi ve sosyolojik bağlamda şu şekilde tanımlayabiliriz:

NÂS (İnsanlar; İnsan Toplulukları, Ümmetler) = İslâm Ümmeti (Müslüman Topluluklar) + Diğer Ümmetler (Diğer İnanç-Etnik Topluluklar).

Bu tanımdan hareketle her bir ümmet, mensubiyet duygusu ile bir araya gelmiş insanlardan meydana gelen bir topluluk veya sosyal gruptur (Aydın, 1991, s. 37). Hz. Muhammed de bütün Medinelileri, dil, din, 1rk ve cinsiyet fark1 gözetmeksizin Nâs olarak görmüş ve bu çerçevede bir medeniyet projesi olarak birlikte yaşama modeli oluşturmuştur.

\section{Olağanüstü Kamusal Giderlerin Ortaklaşa Paylaşılması}

Hz. Muhammed, Medine'ye hicretinde hazırladığ1 kurucu yasada kamusal gelir ve giderlere de yer vermişti. Buna göre, kabileler kendi içlerinde bazı ödemelere iştirak edeceklerdi. Ayrıca yasanın 24, 37 ve 38. maddelerinde Müslim ve Gayri-Müslimlerin birlikte giriştikleri savaşlarda masraflara eşit bir şekilde iştirak edecekleri belirtilmektedir. Başka bir ifadeyle genel savunma giderleri, ortaklaşa karşılanacak ancak Medine savunmasının dışındaki gruplar arasında meydana gelebilecek dinî bir savaşın gideri cemaatlerin kendine ait olacaktı (Aydın, 1991, s. 119).

Toplumsal uzlaşma ve ortak akıl sayesinde ortaya çakan Medine vesikası (kurucu yasa), şüphesiz anayasal sosyal hukukun oluşumu ve gelişimi açısından sadece bir başlangıçtır. Medine vesikası, hangi ırk ve hangi milletten olursa olsun millî güvenlik (can güvenliği) içinde barışçı bir şekilde birlikte yaşama modeli ekseninde bütün vatandaşlarına din ve vicdan özgürlüğü, sosyal hayata katılım, hür teşebbüs ve mülk edinme hakk1 vermektedir. Bundan sonra miras, ticaret (faiz yasağı) ve sadaka (zekât) ile ilgili ayetlerin gelmesiyle birlikte, İslâm devletinin sosyo-ekonomik ilkelerinin genel çerçevesi daha belirgin hâle gelmiş ve tarihte ilk kez vahiy kaynaklarıyla şekillenen bir sosyal devlet modeli ortaya çıkmıştır.

\section{Gayri-Müslimlerin Sosyal Koruma Altına Alınması}

Müslümanlar, ilk dönemlerde yoksul gayri-Müslim akrabalarına da infakta (maddî destekte) bulunuyorlardı. Hicretle birlikte zengin Müslümanların sayısının az ve fakir Müslümanların sayısının da fazla olmasından dolayı Hz. Muhammed, Medine vesikasına binaen ilk önce kendi ümmetini düşünerek, "Sadece kendi dindaşlarına tasaddukta bulunun" şeklinde bir tavsiyede bulunmuştu. Ancak; Allah, Hz. Muhammed'in bu tavsiyesini uygun bulmamış ve kendisine hemen uyarı mahiyetinde aşağıdaki ilgili ayeti göndermiştir.

"Ey Peygamber! Onları (gayr-i Müslimleri) hidayete erdirmek senin üzerine bir borç değildir. Zira ancak Allah dilediğini hidayete erdirir. Hayır olarak ne harcamada (sadakada) bulunursanız, bu kendi faydanızadır. Yapacağınız hayırları (sadakaları) ancak Allah'ın rızasını kazanmak için yapmalısınız. Çünkü yapacağınız her iyilik, size olduğu gibi geri dönecek ve size asla haksızlık yapılmayacaktır." (Bakara: 2/272).

Böylece Kur'an, sadece (yoksul) Müslüman vatandaşlara değil, zimmî statüsünde olan GayriMüslimlere de genel anlamda sadakanın, dar anlamda zekâtın verilmesi gerektiğini ifade etmektedir. Gayri-Müslimlere sadakayı mubah kılmak üzere inen bu ayet, (muhtaç) insanlar arasında ayrımın yapılmamasını öngörmektedir (Aydın; 1991, s. 119). Taberî, bu ayete şöyle bir yorum getirmektedir: "Ey Muhammed! Müslüman olmayanların İslâm'a girmek suretiyle hidayet bulmaları senin üzerine borç değil ki onlara sadakaların verilmesine engel oluyorsun. İhtiyaçları olur da hiç değilse o yolla İslâm'a girerler diye sadakalardan onlara bir şey vermiyorsun. Yarattıklarından dilediğinin İslâm'a girerek, hidayet bulmasını sağlayacak sadece O'dur. Bu sebeple onlara verilecek sadakayı engelleme." (Taberî,1420/2000, s. 94). 
Bu ihtar mahiyetindeki ilahî mesaj üzerine Hz. Muhammed, zengin ve varlıklı Müslümanlara, tasaddukta bulunurken, diğer din ve irklara mensup yoksul insanları da düşünmeleri gerektiğini hatırlatmış ve kendisi bu konuda örnek davranışlarda bulunmuştur. Mesela sadaka (zekât) ve ganimetten kendi hissesine düşen paydan Müslüman olmayan yoksullara da vermiş ve bunun için tahsisatta bulunmuştur (Köse, 2009, s. 54-55).

Kur'an, Medine'de inen başka bir ayetinde de Müslümanlarla barış içinde yaşamak isteyen GayriMüslimlere iyilikte bulunulması gerektiğinin altını çizmeye devam etmiştir:

"Allah sizi, din konusunda sizinle savaşmamış, sizi yurtlarınızdan da çıkarmamış kimselere teberruda bulunmaktan (iyilik etmekten), onlara âdil davranmaktan men etmez. Şüphesiz Allah âdil davrananları sever. Allah, yalnız sizinle din uğrunda savaşanları, sizi yurtlarınızdan çıkaranları ve çıkarılmanız için onlara yardım edenleri dost edinmenizi yasaklar. Kim onlarla dost olursa işte zalimler onlardır." (Mümtehine: 60/8-9).

Ayette geçen teberru kavramı, hayırlı işlerde yani toplumsal faydası olan durumlarda din ayrımı gözetmeksizin yardım ve ihsanda bulunmanın önemine işaret etmektedir. "Birlikte Yaşamının Modeli”nin uygulayıcısı olarak Hz. Muhammed, bir keresinde Vadi'l Kura'ya ulaştığında Benî Ariyd isminde bir Yahudi kabilesine Vadi'l Kura hurmalarından her yıl verilmek üzere geçimlik temin etmiştir. Bu hak, yazılı bir vesika ile de tescil edilmiştir (Ülkü, 2001, s. 135).

Hz. Muhammed, Medine dışında yaşayan ve maddî yönden zor durumda olan Gayri-Müslimlere de insanlık namına sosyal yardımda bulunmuştur. Mekke halkının kuraklık ve kıtlıktan dolayı temel ihtiyaçlarını karşılamada zorlandığını duyunca Medine Devletinin Başkanı olarak Hz. Muhammed, hicrî 5. yılda Mekke'ye en güvendiği sahabilerinden biri olan Amr bin Ümeyye ile arpa, altın ve hurma çekirdeği göndermiştir. Mekke'nin ileri gelenlerinden olan Ebu Süfyan, gönderilen yardımlarının bütününü aldıktan sonra Kureyşilerin yoksullarına dağıttı ve memnuniyetini ifade etmek adına şöyle dedi: "Allah, kardeşimin oğlunu hayırla mükâfatlandırsın. Çünkü O, akrabalık hakkını gözetti.” (Köksal, 2007, s. 564)

Hz. Peygamber, Medine İslâm devletinin dışında yaşayan, açlık ve ölüm tehlikesiyle karşı karşıya kalan Mekke müşriklerine acil sosyal yardımda bulunduğuna göre bir İslâm toplumunun veya devletinin zimmî statüsünde olan yerli Gayri-Müslimleri de sosyal koruma altına alması her halükârda elzemdir (Ülkü, 2001, s. 135). Bütün bunlardan çıkan netice başta yerli Gayri-Müslimler olmak üzere her nerede yaşarlarsa yaşasın muhtaç durumunda olan bütün insanlara sosyal yardımda bulunmak, birlikte yaşama modelinin küresel çapta da geçerli olduğunu göstermektedir.

\section{Sonuç}

Medine'nin karmaşık sosyal yapısı, hicretle birlikte yeni bir şekil almaya başlamıştır. Evs ve Hazrec kabileleri, İslâm kardeşliği çatısı altında sosyal yardımlaşmayı esas alan Ensar unvanını elde ederken, Mekke'de icra edilen biatlerin yanında Medine'de akdedilen vesikayla muhacirlerle birlikte bir İslâm ümmeti konumuna yükseldi. Bu ümmetin üyelerini birbirine bağlayan tek unsur, inanç birliğiydi. Müslümanlar arasında sağlanan "birlikte yaşama modeli", İslâm'ın evrensel mesajları açısında yeterli değildi (Sallahi, 2017, s. 560-561).

Onun için Hz. Muhammed, hiçbir dinî ve etnik ayrımcillk yapmadan bütün insanların temel fitrî ve sosyal ihtiyaçlarını tam olarak karşılanmasını güden kapsamlı bir "Birlikte Yaşama Modeli” tasarladı. Bu doğrultuda inanç ayrımı gözetmeksizin diğer dinlere mensup Medinelileri de bir ümmet olarak kabul etmiş ve "Sizin dininiz (hayat tarzınız) size, benim dinim de bana..." (Al-i İmran: 109/6) ayetin sosyal mesaj1 ekseninde Gayri-Müslimler de "birlikte yaşama modeli"ne dâhil edilmiştir. Böylece Medine'de yaşayan herkes, vatandaşlık statüsüne elde ederek, anayasal çerçevede sosyal koruma kapsamına alınmış oldu.

Hangi din, 1rk ve kültürden olursa olsun herkesin dâhil olabileceği bir "Birlikte Yaşama Modeli”nin temel ilkesinin bir üst kimlik olarak insanlık olduğunu söyleyebiliriz. Bu anlamda dünyada yaşayan bütün insanlar, insanî (tarihî; genetik, fitrî) boyutuyla ilk insan ve ilk Peygamber Hz. Âdem'in evlatları olmaları hasebiyle küresel ailenin fertleri olarak görülmüsstür (görülmektedir). Nitekim Veda Hutbesinde $\mathrm{Hz}$. Peygamber, bütün insanların aynı atadan geldiğini ve bundan dolayı da dünyevî kriterler açısından eşit olduklarına vurgu yaparak, evrensel sosyal mesajını şu şekilde vermiştir "Ey insanlar! Şuna dikkat ediniz ki, sizin Rabbiniz birdir; babanız (atanız) birdir. Arabın Arap olmayana, Arap olmayanın Araba; beyazın siyaha, siyahın beyaza Allah korkusu dışında hiçbir üstünlüğü yoktur”. 
Nitekim Veda Hutbesinde Hz. Peygamber, bütün insanların aynı atadan geldiğini ve bundan dolayı da hangi irktan olursa olsun dünyevî/hukukî kriterler açısından eşit olduklarına vurgu yaparak, evrensel sosyal mesajını şu şekilde vermiştir: "Ey insanlar! Şuna dikkat ediniz ki, sizin Rabbiniz birdir; babanız (atanız) birdir. Arabın Arap olmayana, Arap olmayanın Araba; beyazın siyaha, siyahın beyaza takva (Allah korkusu) dışında hiçbir üstünlügü yoktur.” (Hanbel, 1982, s. 411).

Toplumun çok kültürlü özelliklerini de dikkate alan "Birlikte Yaşama Modeli”nde her yurttaş, bir alt kimlik olarak kendi dinî inançlarına bağlı kalarak, yaşama hakkına sahiptir. Böylece "birlikte yaşama modeli"nin her bir üyesi, sadece kendi kavminden, milletinden ve(ya) dininden olan ve dolayısı ile kendi alt kimliğine bağlı olan insanlara değer vermekle kalmamalı, farklı din, kültür, ırk ve dillerin mensuplarına da merhametin bir gereği olarak ihtiram (sayg1) göstermelidir. Bu ihtiramı göstermeyip "birlikte yaşama modeli"nin temel ilkelerini çiğneyenler, millî mutabakatın sonunda oluşan anayasal devlet tarafindan cezalandırilmaya hak etmektedir.

İslâm'da devlet kurmak, bir amaç mıdır yoksa araç mıdır, dinî olmaktan çok aklın veya "Birlikte Yaşama Modeli"nin getirdiği zaruretlerin bir gereği midir şeklinde yapılan tartışmalar her zaman gündemde olmaktadır (Aydın, 1991, s. 214). Hakikat şu ki, Hz. Muhammed, İslâm dinini geniş kitlelere tebliğ edebilmek için, ilk önce bir İslâm toplumuna, belirli bir sayıya ulaştıktan sonra da Müslümanların sosyal ve siyasî sistemlerini özgürce hayata geçirebilmeleri maksadiyla dünyevî araçlara ihtiyaç duymuştur. $\mathrm{Bu}$ araçların başında hukukî çerçevesi belirlenmiş olan "Birlikte Yaşam Modelì" nin hayata geçirilmesi ile birlikte bunun sürdürebilirliğini sağlamak maksadıyla siyasî bir teşkilat olarak vahye dayanan yeni bir devlet sisteminin oluşturulması gelmiştir.

Medine vesikasının uygulanması ile sadece "Birlikte Yaşama Modeli”nin temelleri atılmamış aynı zamanda adaleti esas alan bir site devletinin kurulmasının da önü açılmıştır. Bu süreçte peygamberliğin (dinî liderliğin) yanında dünyevî anlamda sosyal ve siyasî lider konumuna gelen Hz. Muhammed, tebliğ maksatlı olarak çeşitli bölgelere eğitimli sahabiler göndermek suretiyle İslâm'ın sosyal barışa önem veren bir din olduğunu ilan etmek istemiştir (Rana, 1985, s. 10-11).

Hicret ile birlikte yoksulluğun had safhada olduğu ilk dönemlerde Müslümanlar arası sosyal yardımlaşmayı tesis etmek adına gönüllü sadakalar teşvik edilmiştir. Daha sonraki dönemlerde ise bu sadakalar, farza dönüşmüş ve kamusal idare altında yardıma muhtaç bütün insanların yararlanabileceği bir zekât müessesesi ihdas edilmiştir.

Bir devlet başkanı sıfatıyla Hz. Muhammed, değişik bölgelerde yaşayan zengin Müslümanlardan zekât vergisini toplayabilmek için, tahsildarlar (âmiller) göndermiştir. Bir sosyal vergi türü olan zekât gelirleri, tahsildarlar aracıllğıyla Medine İslâm Devletine ulaştırılır ulaştırılmaz Hz. Muhammed tarafindan Kur'an-1 Kerim'de belirtilen kişi ve gruplara hemen dağıtılırdı (Rana, 1985, s. 11).

Böylece "Birlikte Yaşama Modeli"nin sürdürebilirliği, ancak İslâmî esaslara göre oluşturulan (oluşturulması gereken) bir sosyal hukuk devlet modeli ile sağlanabilmiştir (sağlanabilecektir). Nitekim Raşit Halifeler döneminde ateş tapınakları ile bilinen Mecusiler de kitap ehli olarak sayılmış, kendileriyle yapılan zimme anlaşmaları sonucunda cizye ödemek şartıyla İslâm Devletinin teminatı altına alınmış ve elde ettikleri temel insan hakları çerçevesinde inançlarını özgürce yaşayabilmiştir. Zimme hukuku temelinde karşıllklı hak ve mesuliyetlerin belirlenmesine bağlı olarak Mecusiler de "Birlikte Yaşama Modeli”nin özgür bir üyesi olabilmiştir (Kara, 2019, s. 66-67).

\section{Etik Beyan}

“Hz. Muhammed (sav) Döneminde Çok Kültürlü Toplumsal Yapısıyla Medine'de "Birlikte Yaşama Modeli”"nin Temelleri” başıklı çalışmanın yazım sürecinde bilimsel, etik ve alıntı kurallarına uyulmuş; toplanan veriler üzerinde herhangi bir tahrifat yapılmamış ve bu çalışma herhangi başka bir akademik yayın ortamına değerlendirme için gönderilmemiştir.

\section{Kaynakça}

Ağırakça, A. (2016). Dünyanm ilk anayasası: Medine vesikeası. İstanbul: Derin Tarih Kültür Yayınları. Aşur, M. (2000). İslam insan ve toplum felsefesi. İstanbul: Rağbet Yayınları.

Aydın, M. (1991). İlk dönem islam toplumunun şekillenmesi. İstanbul: Pınar Yayınlar1.

Bostanc1, A. (2001). Kamu bukuku açısından H₹: Peygamber'in gayri müslimlerle iliskileri. İstanbul: Rağbet

Yayınlar1.

Buharî. (1401/1981). Sabibu'l-Buhârî. İstanbul: Çağrı Yayınları. 
el-Haccâc, M. b. (1401/1981). Sabîhu Muslim. İstanbul: Çağrn Yayınlar1.

Gadban, M. (1990). İslam'da siyasi anlasma. Adapazarı: Nass Yayınları.

Hamidullah, M. (1992). Illk islam devleti. İstanbul: Beyan Yayınları.

Hamidullah, M. (1993). İslam peygamberi (bayatı ve faaliyeti) 2. İstanbul: İrfan Yayımcllı.

Hanbel, A. B. (1982). Müsned. İstanbul: Çağr1 Yayınlar1.

Hisâm, İ. (1985). Es-Sîretu'n-Nebeviyye l'İbn Hişâm. Beyrut: Dâru İhvâi't-Turâsi'l-Arabi.

Kara, C. (2019). Mecusiler ehl-i kitabın haklarına sahip oldular. Derin Tarih Özel Sayı 14, x(y), xx-yy, 66-67

Kolektif. (2016). İslam ansiklopedisi. İstanbul: Türkiye Diyanet Vakfi.

Köksal, M. (2007). Peygamberler peygamberi H₹: Mubammed ve islamiyet: Medine devri. İzmir: Işsk Yayınları.

Köse, S. (2009). Müslüman düşüncesinde insanın insanlığ1 sebebiyle saygınlı̆̆ının zirve noktası-gayr-i

müslimlere yardımın mali ibadet kapsamında oluşu. İslam Hukuku Araștırmaları, 14(14), 49-66.

Kundurac1, N. F. (2012). İslam medeniyetinin oluşumunda sosyal sermaye. Ondokuz. Mayıs Üniversitesi İlabiyat Fakïltesi Dergisi, 33(33), 191-226.

Rana, İ. (1985). Hæ: Ömer dönemindeki ekonomik yapr (Çev: A. Kot) İstanbul: Bir Yayıncillk.

Rûdânî. (2008). Cem'ul-Fevaid min Cami'il-usul ve Mecmua'iz-zevaid. (Çev: H. Yıldız) İstanbul: Ocak Yayıncılık. Sallahi, A. (2017). Siyer-i Nebi. İstanbul: Ravza Yayınları.

Sarıçam, İ. (2007). Hæ. Muhammed ve evrensel mesaj. Ankara: Diyanet İşleri Başkanlığı.

Sırma, İ. (1994). İslâmî tebliğin medine dönemi ve cihad. İstanbul: Beyan Yayınları.

Sönmez, A. (2007). Rasullah'in diplomatik münasebetleri ve barış andlasmalar. İstanbul: İnkılab Yayınc1l1k.

Taberî. (1420/2000). Câmi'u'l-beyân an Te'vili âyi'l-Kurân. Beyrut: Müesestu'r-Risâle.

Ülkü, H. (2001). Başlangıçtan günümüre islâm taribi. İstanbul: Akit Yayınları.

Wellhausen, J. (1889). Medina vor dem Islam: Muhammads gemeindeordnung von Medina: Seine schreiben und die gesandtschaften an ihn, Skizzen und Vorarbeiten IV. Berlin.

Yardım, A. (1998). Peygamberimizin șemâili. İstanbul: Erkam Yayınları.

Yeniçeri, C. (1994). Asr-ı saadette devlet bütçesi: Bütün yönleriyle asr-ı saadet'te islâm. İstanbul: Beyan Yayınları.

\section{EXTENDED ABSTRACT}

As a human being prophet Muhammed (p.b.u.), notified the Islam to people with the ideal of "living together model" which contains mutual respect instead of hostility. Unfortunately the polytheists of Mecca, were against the divine message of Muhammed (p.b.u.), they both behaved badly Muhammed (p.b.u.) and few Muslims. The disbelievers had called him a soothsayer, madman, a poet and a lier. The polytheists of Mecca had implemented socio-economic boycott for three years to all Muslims whose number started to increase day by day (A.D 616-619), for this reason living freely in Mecca became more difficult for Muslims. Persecution and torture increased and life grew unbearable fort the Muslims in Mecca. Being constantly in danger Muhammed (p.b.u.) and his companions prepared quietly to leave Mecca and to migrate to the city of Medina, two hundred and fifty miles away from Mecca. Because all Muslims who were living in Mecca were given the permission of migration by Allah.

Receiving the loyalty statement from a Muslim delegation of Medina so-called "Akabe Biatı", Muhammed (p.b.u.) prepared the foundation for migration to Medina. The Muslims in Medina had offered their homes and welcomed all Muslims to live in the security and safety of their city. This was an important turning point in Islamic history, from which date the Islamic calendar began with the birth of a well-organized Muslim community. This was also the second phase in the mission and life of the Prophet (p.b.u.) because the first Islamic state could be established by the Prophet (p.b.u.) as an accepted head of this state by all the citizen of Medina.

Other than Muslims the other citizens like pagan Arabs and the "people of book" Jews and Christians) wanted the Prophet (p.b.u.) to bring peace and justice to their city torn by tribal feuds and unrest. Because Medina might well be a major economic and cultural power in the region, but it also had a tradition of internal conflicts. There had always been a cult of proud tradition of hard tribal warfare. So Medina, was a city in where tribal and religious wars were common practice. So almost all citizen of Medina were convinced that the Prophet (p.b.u.) would be able to put an end to the long tribal feud there and introduce peace and security for all people independent of their religion or confession of faith.

After the migration to Medina the scope of "Living Together Model" which was carried out at first between the two Muslim groups Ensar (Muslims of Medina) and Muslim immigrants from Mecca was developed. As a part of the "Living Together Model" the non-Muslims of Medina had been included to the new social order. The "Living Together Model" based on a Constitution contained a wealth of new 
regulations and arrangement. It was the first Charter of Human Rights and Liberties which guaranteed every citizen peace, justice, freedom, security and cultural, material wealth. The main contents of the "Living Together Model" document can be briefly described in the following way:

- After the proclamation of the common federal state and the establishment of the first "Medina Document" the Prophet (p.b.u.) was recognized as a political leader. Despite his leadership he (p.b.u.) was always an attentive and social statesman and, in spite of his extraordinarily successful activities his compassion towards the needy, his mercy towards those who suffer demonic oppression was impressive.

- Respect for the freedom of conscience, expression, religion and belief and for the right of association for all citizen of Medina and environment without any discrimination.

- The citizen of Medina have a joint responsibility for their local peace. So they have to guard in cooperation their security and protection from any outside threat or attack.

- A fairly partcipation in the extraordinary public spendig especially in the defense expenditure

- Justice and the abolition of all crime and immoral practices.

- Social security for all poor citizen and people of need without discrimination. 'Zakah', one of the financial pillars was established during this time in the social system. 'Zakah', the wealth tax due to help poor and needy was an effective instrument to fight against poverty. Rich Muslims had to pay this social tax to the Islamic state. As a political leader of this state of Medina the Prophet (p.b.u) distributed the 'Zakah' revenue to all poor citizen without any religious stint. Social justice, compassion and charity were one of the main features of the "Living Together Model".

So in this study, the principles of the "living together model", which includes different religion communities, will be researched. The aim of our study is to show that the "Living Together Model" of Muhammed (p.b.u.) will be able to contribute to solve still today the social problems of a world where global racism and violence are increasing. 